\title{
Analysis of meteoric iron from Burlington, Ostego county, New York
}

\author{
Mr. C.H. Rockwell
}

To cite this article: Mr. C.H. Rockwell (1846) Analysis of meteoric iron from Burlington, Ostego county, New York, Philosophical Magazine Series 3, 28:185, 154-154, DOI:

10.1080/14786444608645380

To link to this article: http://dx.doi.org/10.1080/14786444608645380

曲 Published online: 30 Apr 2009.

Submit your article to this journal $\sqsubset \pi$

Џ Article views: 2

Q View related articles $\square$ 
discrepancy as to the state of oxidation of the latter, tend to show a close connexion between the Elie mineral and pyrope. The occurrence of oxide of chromium in both minerals, and their specific gravity, which is 3.661 for the Elie mineral, $3 \cdot 78$ for pyrope, while that of precious garnet exceeds $4^{\circ}$, lead to a similar view of this connection.-Jameson's Journal, Oct. 1845.

\section{ANALYSIS OF METEORIC IRON FROM BURLINGTON, OSTEGO COUNTY, NEW YORK. BY MR. C. H. ROCKWELI.}

In the year 1819 two or three masses of native iron, as it appeared to be, were procured from the farmer who first turned it over with his plough, in a field near the north line of the town of Burlington, Ostego County, New York. These consisted of remnants of an entire mass originally supposed to weigh between one and two hundred pounds, and found several years before. It had been in the forge of a country blacksmith, and the whole heated in order to enable him to cut off portions for the manufacture of such articles as the farmer most needed.

The mass was divided by broad laminæ, crossing each other at an angle of $60^{\circ}$ and $120^{\circ}$, cutting up the surface into triangular and rhombohedral figures. It broke with a hackly fracture, and only with the greatest difficulty on the thinnest edges.

Two deep and broad sutures marked its two most regular opposite faces, made by the wedge or chisel by the smith, who severed it from the adjoining portion. It bore the marks of having been intensely heated in the forge, and numerous microscopic crystals, of a black colour and brilliant lustre, covered some parts of its surface; they resembled phosphate of iron, but were too small to be detached.

The specific gravity was 7.501 ; it dissolved quickly and completely in nitric acid, with the application of a gentle heat. 'The solution, treated with nitrate of silver, gave no cloudiness, showing the absence of chlorine; it yielded by the usual process for separating iron from nickel,

$$
\begin{array}{rr}
\text { Iron . . . . . . . . } & 92.291 \\
\text { Nickel . . . . . . } & 8.146 \\
\hline 100.437
\end{array}
$$

No trace of any other substances could be detected.-Silliman's Journal, vol. xlvi.

\section{PREPARATION OF CHLORO-ACETIC ACID.}

M. Malaguti recommends the following process for the preparation of chloro-acetic acid readily and in large quantity :- Let chlorine act upon sulphuric ather, by which sesquichloride of carbon is obtained, and then the water which is suffered to remain in the bottles with the rough product is merely a solution of chloro-acetic and hydrochloric acids; or perchloric ather is prepared, and by distilling it and causing the product of the distillation to mix with water, a solution of chloro-acetic and hydrochloric acids is obtained. In both 